\title{
RELATIONSHIP BETWEEN THE EU AND NATO BASED ON THE EXAMPLE OF DATA PROTECTION POLICY
}

\begin{abstract}
On 24 May 2018, the General Data Protection Regulation (GDPR) entered into force, thereby obliging all 28 national legal systems of the EU Member States to harmonize and supplement their rules on the protection of personal data. From the perspective of international law, agreements emanating from other international organizations that are binding on the EU Member States may prove to impose legal obligations inconsistently with the GDPR. Possibly, an example of such an international organization may be NATO. In such a case, the EU Member States would be confronted with an irresolvable conflict of law, as - from the horizontal system of international law - they would be obliged to abide by the rules of both Organizations. Given that as many as 22 EU Member States are Parties to NATO, this study examines whether there is a legal or a political requirement to implement the GDPR to the policy of NATO.
\end{abstract}

\section{Keywords}

conflict of law - data protection policy - EU - GDPR - international organizations NATO - public international law

* Maastricht University (LL.B. 2018, LL.M. candidate 2020), Nicolaus Copernicus University in Torun (Master of Law candidate 2021). Research for the purpose of this study has been conducted at the Office of the Legal Advisor at NATO Joint Force Command Brunssum; e-mail: inzapa@tlen.pl. 


\section{INTRODUCTION}

Personal data protection policy may be understood as the area of law that provides for norms regulating the processing of personal data. This includes the rules on obtaining, transferring, as well as using these data by the entities who received them. The regulation of this activity is of the utmost importance, given e.g. the risks associated with the release of personal data such as using the obtained information for malicious purposes. For example, the US Federal Emergency Management Agency accidently released private data from 2.3 million disaster survivors of hurricanes of 2017, which has been considered to be a "major privacy incident" ${ }^{1}$. In 2015, Northamptonshire county council accidentally published data of almost 1.500 children including names, addresses, religion, and special educational needs status ${ }^{2}$. In 2012, the Torbay Care Trust released personal details of over 1.000 NHS staff online, leaving them open to identity theft ${ }^{3}$. Even though these entities may not have intended to use the released data for malicious purposes, there is a risk that this may still happen as a result of the activities of other parties. A survey conducted by McAfee in 2018 reveals that $43 \%$ of people (out of almost 7.000) feel they do not have control over their personal information ${ }^{4}$. For the sake of the abovementioned, the data protection policies have been under constant development at national level ${ }^{5}$. It may be argued that, in

${ }^{1}$ B. Kesling, FEMA Officials Accidentally Released Private Data From 2.3 Million Disaster Victims, available at: https:/ / www.wsj.com/articles/fema-officials-accidentally-releasedprivate-data-from-2-3-million-disaster-victims-11553306354/ [last accessed 26.4.2019].

${ }^{2}$ R. Ramesh, Public bodies are releasing confidential personal data by accident, available at: https:/ / www.theguardian.com/technology/2015/jul/15/confidential-personal-datarelease-accident-councils-nhs-police-government/ [last accessed 26.4.2019].

${ }^{3}$ Press Association, NHS trust fined $£ 175,000$ for 'troubling' data security breach, available at: https:/ / www.theguardian.com/uk/2012/aug/06/nhs-trust-fined-data-security/ [last accessed 26.4.2019].

${ }^{4}$ G. Davis, Key Findings from our Survey on Identity Theft, Family Safety and Home Network Security, available at: https:// securingtomorrow.mcafee.com/consumer/keyfindings-from-our-survey-on-identity-theft-family-safety-and-home-network-security/ [last accessed 26.4.2019].

${ }^{5}$ Cf. recent changes in Brazil: Consumer Protection Code of 1990, Internet Act of 2014 regulates the protection of privacy and personal data online, General Data Privacy 
general, more stringent rules offer a higher protection to data subjects, thereby ensuring their right to privacy and security. Simultaneously, however, they limit other freedoms, e.g. autonomy to shape their own policies by entrepreneurships, which are surrounded by new obligations and a fear of the imposition of fines for not complying with them.

The data protection policies have not only been governed by national legislation. Faced with possible dangers and in fear of the lack of a proper security mechanism, the European Union (EU) decided to implement necessary reforms as well. Even though the Organization had the relevant legislation in place (Data Protection Directive ${ }^{6}$ ), it was decided to repeal it by the General Data Protection Regulation (GDPR $)^{7}$. This generally and directly applicable legislation (Art. 288 TFEU) was enacted on 27 April 2016 and entered into force on 24 May 2018. It specifies various definitions, such as personal data - any information relating to an identified or identifiable natural person ${ }^{8}$, and processing - any operation which is performed on personal data, whether or not by automated means, such as collection, recording, storage, use, disclosure, erasure, or destruction ${ }^{9}$. It provides for the principles relating to the processing of personal data

Law of 2018; Germany: Federal Data Protection Act of 2001 was replaced by the Federal Data Protection Act of 2017; Iceland: Processing of Personal Data of 2000 was replaced by the Data Protection and the Processing of Personal Data of 2018; Sweden: Personal Data Act of 1998 was replaced by the Swedish Data Protection Act and the Swedish Data Protection Regulation of 2018. See: K. Yahnke, A Practical Guide to Data Privacy Laws by Country, available at: https:/ / i-sight.com/resources/a-practical-guide-to-data-privacylaws-by-country/ [last accessed 26.4.2019].

${ }^{6}$ Directive 95/46/EC of the European Parliament and of the Council of 24 October 1995 on the protection of individuals with regard to the processing of personal data and on the free movement of such data, OJ L 281, 23.11.1995, p. 31-50 (no longer in force).

7 Regulation (EU) 2016/679 of the European Parliament and of the Council of 27 April 2016 on the protection of natural persons with regard to the processing of personal data and on the free movement of such data, and repealing Directive 95/46/EC (General Data Protection Regulation) (Text with EEA relevance), OJ L 119, 4.5.2016, p. 1-88, hereinafter to be referred as 'GDPR'.

8 Art. 4.1 GDPR.

9 Art. 4.2 GDPR. The full wording of the provision reads as follows: "'processing' means any operation or set of operations which is performed on personal data or on sets of personal data, whether or not by automated means, such as collection, recording, organisation, structuring, storage, adaptation or alteration, retrieval, consultation, use, 
(Art. 5) as well as legal grounds for the processing (Art. 6). Furthermore, it prohibits the processing of "special categories of personal data", the so-called sensitive data, i.e. revealing racial or ethnic origin, political opinions, religious, or philosophical beliefs, or trade union membership, and the processing of genetic data, biometric data for the purpose of uniquely identifying a natural person, data concerning health or data concerning a natural person's sex life or sexual orientation (Art. 9.1). The prohibition may be lifted only if the grounds listed by Art. 9.2 have been met; one of such grounds being the consent of a data subject.

The rationale behind the GDPR is the protection of natural persons (Rec. 14). Having analyzed the rules stemming therefrom, it is clear that the purpose of the Regulation is to impact both private and public sectors. In the private area, a distinction may further be made between natural persons and private establishments. Public category comprises inter alia public official institutions. To give an example, natural persons receive new rights and at the same time they are supposed to respect the rights of other persons; in addition to that, companies are responsible for carrying out the Data Protection Impact Assessment (Art. 35), whereas governments are to set up new bodies (such as the Supervisory Authority, Art. 51).

Having in mind the constant development in the area of public international law, it may be argued that the impact may have even further consequences. By entering new treaties, States bind themselves with new obligations. There are two implications that may occur with respect to the EU norms, once a Member State concludes a new international agreement. The new rules entered into may be in compliance or in conflict with the currently binding law of that Organization. The same finding applies to a new piece of EU legislation in relation to the already-enforced law of an international organization, to which its Member State is a party. An example of an international organization that comprises a number of the EU Member States is the North Atlantic Treaty Organization (NATO).

The aim of this study is to examine the correlations of the data protection policy between the EU and NATO. More specifically, the 
purpose of the paper is to answer the following question: "Given the responsibilities imposed on the EU Member States, is NATO required to implement the General Data Protection Regulation, and what are the rules on accountability in the case of adopting and abiding by measures that are inconsistent with this Regulation?" To narrow down the scope of the research, for the purposes of the examination, 'NATO' shall be understood as the Joint Force Command in Brunssum (JFCBS), the Netherlands. The relevance of the examination is twofold. Firstly, as presented above, the GDPR has significantly impacted the EU Member States and many private and public sectors therein. Secondly, as of April 2019, the EU (28 Members) and NATO (29 Members) have as many as 22 States in common. Therefore, the answer to the question becomes primarily significant for NATO headquarters that - just like JFCBS - are located within the EU. Considering that the rules of NATO and EU bind their Parties equally, it is emphasized that the findings of the study may apply to any NATO headquarters located within the EU.

This paper is of descriptive and analytical nature inasmuch as it analyzes the currently binding law, jurisprudence, and legal doctrine. To this end, it is divided into three main chapters. The part following the Introduction displays an overview that is relevant for the analysis by presenting the legal nature of the EU (II.1) and NATO (II.2). Subsequently, Chapter III provides the answer to the first part of the research question. On the basis of public international law (III.1.) and the relevant jurisprudence (III.2.), it examines whether NATO is required to implement the GDPR. Based on the findings (III.3.), Chapter IV answers the second part of the research question. It examines possible accountability steps in the case of adopting and abiding by NATO measures that are inconsistent with the GDPR. Based on a hypothetical situation (IV.1), this part studies the standards of the liability of a state (IV.2) and of international organizations (IV.3.) Eventually, the paper finishes with Conclusions and Recommendation $(V$.$) . This is the place for a brief summary of the$ findings and providing the answer to the research question. 


\section{Place of The EU and Nato in National Legal Hierarchy}

\section{THE EUROPEAN UNION}

The EU legal system consists of primary and secondary sources of law. The former includes the founding Treaties, i.e. the Treaty on European Union $\left(\mathrm{TEU}^{10}\right)$ and the Treaty on the Functioning of the European Union (TFEU ${ }^{11}$ ). The secondary sources comprise among others: acts that have been enacted in the framework of a legislative procedure (e.g. ordinary legislative procedure, Art. 294 TFEU), unilateral acts listed in Art. 288 TFEU (regulations, directives, decisions, opinions, and recommendations) as well as agreements (e.g. conventions to which the EU is a party, concluded in the procedure of Art. 218 TFEU). This part of the paper primarily aims at presenting the position of EU law in the national legal hierarchy of its Member States. To this end, attention will be paid to the founding Treaties and the CJEU's interpretation thereof.

The consideration of the validity of EU law in national legal systems cannot be started without referring to the Court's decision in Van Gend \& Loos. The Netherlands submitted a preliminary question (cf. now Art. 267 TFEU) and asked whether Art. 12 EEC Treaty (now: Art. 30 TFEU ${ }^{12}$ ) "has direct application in national law in the sense that nationals of Member States may on the basis of this article lay claim to rights which the national court must protect"13. The Court answered in the affirmative, thereby establishing the first criteria for producing direct effect by an EU provision (clear, unconditional, negative obligation, not qualified by any reservation on the part of a Member State, not dependent on any

${ }^{10}$ Consolidated version of the Treaty on European Union, OJ C 326, 26.10.2012, p. 13-390, hereinafter to be referred as 'TEU'.

${ }^{11}$ Consolidated version of the Treaty on the Functioning of the European Union, OJ C 326, 26.10.2012, p. 1-390, hereinafter referred to as 'TFEU'.

12 Art. 30 TFEU: "Customs duties on imports and exports and charges having equivalent effect shall be prohibited between Member States. This prohibition shall also apply to customs duties of a fiscal nature".

${ }^{13}$ NV Algemene Transport- en Expeditie Onderneming Van Gend \& Loos v. Netherlands Inland Revenue Administration, Case 26/62, Judgment of 5.2.1963, E.C.R. 1963. 
national measure $\left.{ }^{14}\right)$. In the explanation thereto, the Court provided the statement, which - despite the passage of time - still applies in relation to EU law. It held that the Community constitutes "a new legal order of international law for the benefit of which the states have limited their sovereign rights, albeit within limited fields, and the subjects of which comprise not only Member States but also their nationals"15.

In relation to the last point, D. Chalmers reckoned that three transformational developments flowed from the analyzed decision ${ }^{16}$. He listed the following as the consequences of the judgment. Firstly, the central symbols and ideals of (now) EU law. In this regard, the author considered this law to resemble the authority figure of a judge (as it "symbolizes qualities of fairness, justice, and dispassion, and acts as a counterpoint to other authority figures"17) and a leader (as it "gets others to act on the basis of her promises as being more plausible than others"18). Secondly, a system of individual rights and duties ${ }^{19}$. This is visible in the passage that "for the benefit of [a new legal order of international law] the states have limited their sovereign rights (...) and the subjects of which comprise (...) also their nationals". The mentioned quotation implies that individuals, who have met the eligibility criteria, can invoke their rights guaranteed under EU law before their national courts. Thirdly, an autonomous legal order with more power than traditional treaties ${ }^{20}$. The new legal order manifests itself through the self-proclaimed right of 'individuality' and 'specialty' in the system of international law. This is visible in the statement that the EEC Treaty "is more than an agreement which merely creates mutual obligations between the contracting states" 21 .

${ }^{14}$ Ibid.

${ }^{15}$ Ibid.

16 D. Chalmers, What Van Gend en Loos stands for, "International Journal of Constitutional Law", Issue 1, 2014, p. 105-134.

17 Ibid. For further information on authority figures, see: A. Kojève, La notion de l'autorité, Paris: Gallimard, 2004, p. 66-88.

${ }_{18}$ Ibid. For the "political messianism" of the EU, see: J. Weiler, 60 Years since the First European Community - Reflections on Political Messianism, "European Journal of International Law", Issue 22, 2011, p. 303-311.

19 Chalmers, supra note 16.

${ }^{20}$ Ibid.

21 Ibid. 
The preceding analysis, supported by the upcoming paragraph, have explained why neither the EEC Treaty nor its later versions are to be considered as a 'typical' international agreement.

The considerations above refer to the new legal order of (now) EU law from the perspective of international law. Having provided the relevant information, the impact of the judgment must also be analyzed in the light of the national law of the EU Member States. In Costa v. ENEL, faced with a question about the conflict of domestic statutory law with the EEC Treaty, the Court explicitly said that the Treaty created its own order, which upon its entry into force was integrated with the national order of the Member States and as such, is binding upon them ${ }^{22}$. Furthermore, owing to the "special and original nature" of the Treaty, the law stemming therefrom cannot be overridden by domestic legal provisions ${ }^{23}$. This supremacy of (now) EU law correlates with the third observation of Chalmers on the Van Gend \& Loos judgment (autonomous legal order with more power than traditional treaties). Therefore, the new legal order implies inter alia the primacy of (then) Community law over national legislation. It must be underlined that this finding applies to every source of national law, including the constitution (Internationale Handelsgesellschaft ${ }^{24}$ ). Furthermore, in the case of a conflict between national and EU laws, any national court has a power to set aside the former, which was decided in 1979 in Simmenthal ${ }^{25}$. Therefore, to ensure the proper and unequivocal enforcement of EU law, conflicting national provisions are to be disapplied.

Interestingly, in December 2018, the Court provided further elaboration in this matter. In WRM, it informed that only the courts designated to review the validity of a national provision have the power to invalidate the conflicting provisions (striking down ${ }^{26}$ ), whereas all national courts

${ }^{22}$ Flaminio Costa v. E.N.E.L, Case 6/64, Judgment of 15.7.1964, E.C.R. 1964.

23 Ibid.

${ }^{24}$ Internationale Handelsgesellschaft $\mathrm{mbH} v$. Einfuhr- und Vorratsstelle für Getreide und Futtermittel, Case 11/70, Judgment of 17.12.1970, E.C.R. 1970.

25 Simmenthal SpA v. Commission of the European Communities, Case 92/78, Judgment of 5.3.1980, E.C.R. 1980.

${ }^{26}$ The Minister for Justice and Equality and The Commissioner of the Garda Síochana v. Workplace Relations Commission, Case C378/17, Judgment of 4.12.2017, E.C.R. 2017, at par. 34 . 
must be under a duty to give full effect to EU provisions in the exercise of their jurisdiction and thus are able to set aside any national provision that are conflicting with EU law (disapplying ${ }^{27}$ ). Furthermore, the Court confirmed that this power also applies to all State organs, including administrative authorities, if they apply EU law ${ }^{28}$. Taking everything into consideration, it is clear that the impact of EU law on its Member States continues. The starting point, i.e. the new legal order expanded to include the primacy of EU law over any national provision, the obligation to set aside conflicting provisions by national courts and public authorities, and even the power of the latter to disapply conflicting national rules. De facto, due to the impact of EU law, one can no longer talk about a Member State's national legislation stricto sensu. The question about exclusivity and autonomy of domestic rules may be valid if these touch upon any the field enlisted in Art. 4.2 TEU, such as national identities, albeit this is not always the case (cf. e.g. Coman ${ }^{29}$ ).

\section{The North Atlantic Treaty Organization}

Having presented the legal structure of the EU, now it is time to focus on its equivalent at the NATO level. The operation of NATO as an international organization is regulated by four multilateral agreements: the North Atlantic Treaty (NAT, 1949) ${ }^{30}$, the Agreement between the Parties to the North Atlantic Treaty regarding the Status of their Forces (NATO SOFA, 1951) $)^{31}$, the Protocol on the Status of International Military Headquarters set up pursuant to the North Atlantic Treaty (Paris Protocol to NATO SOFA, 1952) ${ }^{32}$ and the Agreement on the Status of the North

27 Ibid. at par. 35 .

${ }^{28}$ Ibid. at par. 38.

29 Relu Adrian Coman and Others v. Inspectoratul General pentru Imigrări and Ministerul Afacerilor Interne, Case C-673/16, Judgment of 5.6.2018, E.C.R. 2018.

${ }^{30}$ North Atlantic Treaty (Washington, 4 April 1949), hereinafter referred to as 'NAT' or 'Washington Treaty'.

31 Agreement between the Parties to the North Atlantic Treaty regarding the Status of their Forces (London, 19 June 1951), hereinafter referred to as 'NATO SOFA'.

32 Protocol on the Status of International Military Headquarters set up pursuant to the North Atlantic Treaty (Paris, 28 August 1952), hereinafter referred to as 'Paris Protocol'. 
Atlantic Treaty, National Representatives and International Staff (Ottawa Agreement, 1951) ${ }^{33}$. The Washington Treaty constitutes the legal basis of NATO. It expresses the goals and principles on which the Organization is founded $^{34}$. NATO SOFA and the Paris Protocol thereto govern situations when forces of one Party serve in the territory of another Party. They regulate the conditions under which the employees are seconded and reside in another NATO State. Moreover, there is a possibility of concluding additional SOFAs between the Parties concerned, which are legally binding on these Parties. Lastly, the Ottawa Agreement regulates the functions of international staff.

The Agreements presented in the previous paragraph were enacted by consensus by all the States that are Parties to $\mathrm{NATO}^{35}$ and are legally binding on all the Members. Having in mind the division of EU law between primary and secondary law, one may consider them to be primary law of NATO, since they were enacted in the first years of the operation of the Organization and provided for norms that constituted the functioning of NATO. However, in the author's view, this EU division may not be reflected at NATO level. This argument is based on two grounds. Firstly, NATO does not have a legislative competence; all decisions are made by consensus ${ }^{36}$. For that reason, one cannot talk about NATO acquis in the form of secondary law as the counterpart of acquis communautaire ${ }^{37}$.

${ }^{33}$ Agreement on the status of the North Atlantic Treaty Organization, National Representatives and International Staff (Ottawa, 20 September 1951).

34 To this effect, see Preamble to NAT: “The Parties to this Treaty (...) are determined to safeguard the freedom, common heritage and civilisation of their peoples, founded on the principles of democracy, individual liberty and the rule of law. They seek to promote stability and well-being in the North Atlantic area".

35 NATO Office of Information and Press, NATO Handbook; 50 th Anniversary NATO 1949-1999, Brussels: Office of Information and Press, 1999, p. 147.

36 T. Gazzini, NATO Coercive Military Activities in the Yugoslav Crisis (1992-1999), "European Journal of International Law", Issue 3, 2001, p. 391-436.

37 The phrase can be translated into English as 'Community patrimony'. It refers to the legal heritage of the EU as well as the entities which were further transformed in the EU. See: C. C. Gialdino, Some Reflections on the Acquis Communautaire, "Common Market Law Review", Issue 32, 1995, p. 1089-1121. Alternatively, the secondary law may be considered to encompass SOFAs concluded between individual States-Parties (an example may be Agreement of 11 December 2009 between the Government of the United States of America and the Government of the Republic of Poland on the Status of The Armed 
Secondly, legal norms enacted by a headquarters are binding only within that headquarters. To give an example, if JFCBS adopts a directive, this directive applies only to personnel of this Command. In this sense, the adopted measures may be considered as internal regulations rather than NATO (secondary) law.

The NATO Treaties do not provide for the judicial structure sensu strict $^{38}$. It seems that the lack of reference to this matter demands the search for an indirect solution, such as the one establishing the Council under Art. 9 NAT. The provision states that the Council shall "consider matters concerning the implementation of this Treaty". If the 'implementation' is accepted to include the dispute settlement stemming from the Treaty interpretation/violation, it can be concluded that the Council, implicitly, shall be a consultative place in dispute settlement. Otherwise, general public international law (e.g. the law of the treaties, the law of state responsibility) must be relied on. An illustrative example may be Art. 33 of the UN Charter, which lists the following methods of peaceful dispute settlement: negotiation, enquiry, mediation, conciliation, arbitration, judicial settlement, resort to regional agencies or arrangements ${ }^{39}$. Furthermore, it is also possible to bring a dispute before the ICJ (see:

Forces of the United States of America in the Territory of the Republic of Poland (effective 31 March 2010)). Nonetheless, these documents are binding only inter partes; contrary to EU secondary law, they do not apply to all NATO States.

38 Art. 24(a) of the Ottawa Agreement provides that the Council shall establish the settlement of "disputes arising out of contracts or other disputes of a private character to which the Organization is a party". This is the provision which became the legal basis for what later became known as the Administrative Tribunal. This body however relates solely to labour-related problems, which is why it is not a proper place to seek justice e.g. when one state aims to bring a claim against another for the violation of certain NAT provisions. The matter resulting from the lack of an internal dispute settlement mechanism was subject to a case brought before the ECtHR. The applicant claimed that Belgium (the receiving State) and Italy (the sending State) had failed to ensure the creation by the Organization of an internal dispute resolution mechanism in compliance with the ECHR; the case was found inadmissible by the Court. See: Gasparini v. Italy and Belgium, App no, 10750/03, Judgment of 12.5.2009.

39 Charter of the United Nations (adopted 24 October 1945) 1 UNTS 16. Cf. Art. 1 NAT: "The Parties undertake, as set forth in the Charter of the United Nations, to settle any international dispute in which they may be involved by peaceful means in such a manner that international peace and security and justice are not endangered". 
Art. 34.1, Art. 35.1, Art. 35.2 and Art. 36.1 of the Statute of the International Court of Justice) $)^{40}$.

Furthermore, pursuant to Art. 8 NAT, each Party "declares that none of the international engagements now in force between it and any other of the Parties or any third State is in conflict with the provisions of this Treaty, and undertakes not to enter into any international engagement in conflict with this Treaty". In accordance with H. Kelsen's opinion, the mentioned 'engagements' are said to primarily encompass international treaties ${ }^{41}$. Furthermore, as reckoned by K. Végh, the term may be understood to comprise any legally binding or non-binding commitments or undertakings that are incompatible with the fulfilment of the legal obligations under the Treaty ${ }^{42}$. Therefore, the Treaty precludes the parties to it from entering into obligations that would be harmful for the values that NATO aims to preserve, such as development of peaceful and friendly international relations (Art. 2), individual and collective capacity to resist armed attack (Art. 3), preservation of territorial integrity (Art. 4), and the principle of collective defence (Art. 5). Taking the foregoing into consideration, it is concluded that in the national legal systems of its Parties, NATO law holds the place typical for an international organization. Although it does not express its primacy as directly (judicial decisions) and as far (obligation to adjust or disapply national law in order to comply with EU law) as the EU, it still requires its Parties to comply with its law. ${ }^{43}$

\section{NATO - REOUUIREMENT TO IMPLEMENT THE GDPR?}

\section{EU AND NATO AS INTERNATIONAL ORGANIZATIONS WITH INDIVIDUAL NORMS}

The following Section will proceed with an analysis concerning the legal relationship between the EU and NATO. The findings thereof

40 Statute of the International Court of Justice (adopted 18 April 1946) 33 UNTS 993.

${ }^{41}$ H. Kelsen, Principles of International Law, New York: Rinehart Company, 1952, p. 150.

${ }^{42} \mathrm{~K}$. Végh, The North Atlantic Treaty and its Relationship to other 'Engagements' of its Parties - A commentary on Article 8 (forthcoming in "Emory International Law Review").

${ }^{43}$ For further discussion, see: P. Klein, La responsabilité des organisations internationales 
will be significant, as only then will it be possible to find out which of the Organizations prevails in the case of conflicting international legal obligations. This will make it possible to answer the question whether NATO is required to implement the GDPR, given that the Regulation has imposed obligations on 22 Members of this Organization. The issue is very important, since the majority of the EU Member States are simultaneously Parties to NATO. Yet, not all EU Member States are parties to this Organization (e.g. Cyprus) and not all NATO States are EU Member States (e.g. Canada).

Pursuant to Art. 26 VCLT $^{44}$, serving as an example of the pacta sunt servanda doctrine, every treaty in force is binding upon the parties to it and must be performed by them in good faith. Accordingly, States that are simultaneously Parties to NATO and EU are obliged to act in conformity with the legal framework emanating from both Organizations.

Double international obligations do not seem to be relatively significant until a legal conflict appears. In the case of an inability to comply with the laws of two international organizations by their common member states, the following question may be rightly asked: can one organization impose obligations on the other? Analogically to Art. 34 VCLT, according to which a treaty does not create either obligations or rights for a third State without its consent, one can exclude such a possibility. As argued by J. Vidmar, in a "horizontal system of legal norms, no legal obligation is prima facie capable of trumping another obligation" ${ }^{45}$. This implies that the supremacy of EU law does not extend beyond its internal system. Therefore, the EU may not impose an obligation on NATO and vice versa, unless otherwise agreed by these Organizations. It seems that the only possibility of solving the problem of a conflict of laws is laid down by public international law. To this end, the general principles such as lex

dans les ordres juridiques internes et en droit des gens, Brussels: Bruylant, 1998, p. 5; A. B. Muñoz Mosquera, The 7 Questions on: International Law, International Organizations \& SHAPE, “NATO Legal Gazette", Issue 2, 2012, p. 5-15

44 Vienna Convention on the Law of Treaties (adopted 23 May 1969, entered into force 27 January 1980) 1155 UNTS 331, hereinafter to be referred to as 'VCLT'.

45 J. Vidmar, Norm Conflicts and Hierarchy in International Law: Towards a Vertical International Legal System?, [in:] E. De Wet, J. Vidmar (eds), Hierarchy in International Law: The Place of Human Rights, Oxford: Oxford University Press, 2012, p. 13-42. 
posterior derogate legi priori may serve as a tool of conflict avoidance with regards to norms between international organizations. Nonetheless, because of the main subject of this study, this point will not be further elaborated.

The problem of conflicting laws concerns the situation of the so-called legal dilemma, i.e. a situation "when an actor confronts an irresolvable and unavoidable conflict between at least two legal norms so that obeying or applying one norm necessarily entails the undue impairment of the other" $^{\prime \prime 6}$. However, there are certain situations, when despite no direct obligation emanating from one organization, the other decides to accept the standards imposed by the former. In such cases, this becomes more of a political than a legal decision ${ }^{47}$, which leads to legal consequences. One of such examples is Art. 42 TEU that refers to the Common Security and Defence Policy (CSDP). Para. 2 states that the policy of the Union shall respect the obligations of certain Member States, which see their common defence realised in NATO and be compatible with the CDSP established within the framework of the Washington Treaty. Moreover, Para. 7 adds that commitments and cooperation in this area shall be consistent with commitments under NATO, which, for those States which are members of it, remains the foundation of their collective defence and the forum for its implementation. In the mentioned provisions replacing Art. V of the Modified Brussel Treaty ${ }^{48}$, the EU explicitly acknowledged that in the area of the CSDP, the norms emanating from NATO are to be abided by its Member States and respected by the EU itself ${ }^{49}$.

${ }^{46} \mathrm{~V}$. Jeutner, Irresolvable Norm Conflicts in International Law: The Concept of a Legal Dilemma, "European Journal of International Law", Issue 28, 2017, p. 1423-1428.

47 D. Bogdansky, Legally Binding versus Non-Legally Binding Instruments, [in:] S. Barrett, C. Carraro, J. de Melo (eds.), Towards a Workable and Effective Climate Regime, London: Centre for Economic Policy Research, 2015, p. 47.

48 R. A. Wessel, Common Foreign, Security and Defence Policy, [in:] D. Patterson, A. Södersten (eds.), A Companion to European Union Law and International Law, New Jersey: Wiley-Blackwell, 2016, p. 394-412.

${ }^{49}$ However, the wording of Art. 42.7 TFEU was de facto a consequence of the conditions for the US support of the Common European Security and Defence Policy, as provided for by the Maastricht Treaty. The requirements (so-called 'three Ds') were expressed by the Secretary of State Madeleine Albright: 1) no discrimination against non-EU NATO 
To refer to a more recent situation, a similar recognition occurred in 2018 with the same actors. This time, however, the acknowledgment was the reverse. In June 2018, the Supreme Headquarters Allied Powers of Europe (SHAPE) decided to base its data protection policy mostly by reliance on the EU General Regulation of Data Protection. This has been evidenced by the ACO Directive 015-026 Data Protection Policy. Soon after, the said Directive became a basis for the data protection policy within the Joint Forces Command in Brunssum (JFCBS). The Command released its version of the document in January 2019 in the form of the JFCBS Directive 025-02 Data Protection. The paper does not examine the consistency of this instrument with the GDPR. Instead, it continues with analyzing whether there had been prior requirements to implement the EU Regulation by JFCBS (III.2.). Furthermore, based on an imaginary problem, it examines the responsibility of the relevant entities as a result of enacting and abiding by hypothetical measures of the JFCBS Directive that are inconsistent with the GDPR (IV).

\section{A. Conclusions}

As established, NATO is not bound by the GDPR, since it is not a party to the EU. The only entities that are directly obliged to abide by this Regulation at NATO level are common Member States of the EU and NATO. These States are simultaneously bound by the norms emanating from both Organizations. It is reckoned that in the case of a conflict between the standards imposed by each Organization, such discrepancies are to be resolved in accordance with the general norms of public international law. The further parts of this contribution will examine the possibility of a conflict prevention technique. In other words, they aim to find out whether there may be an indirect requirement or a legal recommendation of NATO to comply with the GDPR.

members (e.g. Turkey), 2) no diminution of NATO and thus no decoupling of European and North American security, and 3) no duplication of NATO's operational planning system and the Alliance's command structure. See: K. Larres, The United States and the 'Demilitarization' of Europe: Myth or Reality?, "Politique étrangère", Issue 1, 2014, p. 117-130. 


\section{DUE ACCOUNT OF THE TERMS AND OBJECTIVES OF THE MEASURES}

Based on the jurisprudence, one may find another way (next to the general principles of public international law) to tackle the interplay between different organizations. Since NATO does not identify itself by a permanent judicial body relevant for the subject matter, a direct reference cannot be made to this Organization. Instead, it will be referred to the leading decision of the CJEU in the EU-UN relation - Kadi ${ }^{50}$. This is justified by the fact that the analysis will directly focus on one of the Organizations that is subject to this research. Consequently, it may serve as an example showing how to deal with situations when an international organization imposes rights/obligations on its members which are simultaneously parties to another organization.

Before moving to the said judgment, the analysis will start from the Bosphorus case, in which the European Court of Human Rights (ECtHR) dealt with a problem like the one of this research. Bearing in mind distinct systems established by individual international organizations, the Court recognized "the growing importance of international cooperation and of the consequent need to secure the proper functioning of international organisations" ${ }^{\prime 51}$. In fact, the implication in casu concerned as many as three international organizations: the United Nations, the European Union, and the Council of Europe. In May 1993, an aircraft leased by the applicant company from Yugoslav Airlines (JAT) was seized by the Irish authorities. This was accomplished in accordance with an EC Council Regulation which had implemented the UN sanctions regime against the Federal Republic of Yugoslavia (Serbia and Montenegro). In the course of the proceedings, the applicant's lease on the aircraft had expired and the sanctions regime had been relaxed. For that reason, Ireland returned the aircraft directly to JAT. The applicant referred to the ECtHR and based the claim under the protection of property, thereby arguing that he had

${ }^{50}$ Kadi and Al Barakaat v. Council, Joined Cases C-402/05 PEC and C-415/05, Judgment of 3.9.2008, E.C.R. 2008.

51 Bosphorus Hava Yollan Turizm ve Ticaret Anonim Şirketi v. Ireland, App no, 45036/98, Judgment of 30.6.2005, at par. 150. 
borne an excessive burden resulting from the manner in which Ireland had applied the sanctions regime, and consequently, he had suffered a significant financial loss. The Strasbourg Court stated that member states of an international organization (such as the EU) are still liable under the ECHR for "all acts and omissions of its organs regardless of whether the act or omission in question was a consequence [...] of the necessity to comply with international legal obligations" ${ }^{\prime 52}$.

Unlike the EU and NATO, the ECtHR - emanating from the Council of Europe - is a stricte human rights judicial authority. However, its decision teaches two lessons relevant to the general application of international law. Firstly, international obligations imposed by Organization A and accepted by its parties remain in force even if these states enter Organization B. Secondly, the states may still be held liable for an act/failure to act, which consequently leads the violation of norms of Organization A, even as a result of abiding by norms of Organization $\mathrm{B}^{53}$.

Another lesson may be taken from Kadi, which had been decided earlier by the CJEU. The UN Security Council identified Mr. Kadi as a possible supporter of Al-Qaida and imposed sanctions on him (particularly an assets freeze). Because the sanction was later adopted by the EU Regulation, Mr. Kadi challenged it before the EU. The General Court (first instance) refused to review the regulation at stake, claiming that this would be equivalent to reviewing the Security Council's measure. The CJEU (appeal), on the other hand, decided to review the Regulation, arguing that this does not amount to such an activity. The Court stated that because Mr. Kadi had not been informed about the grounds for his inclusion in the list of individuals subject to the sanctions, he could not seek judicial review of the said grounds, which resulted in the violation of his rights to be heard, to effective judicial review ${ }^{54}$, and to the right to property ${ }^{55}$. As argued by J. Kokkot and C. Sobotta, "the judgment of

${ }^{52}$ Ibid. at par. 153.

${ }^{53}$ For other cases with multiple jurisdictions of international organizations, see: Matthews v. United Kingdom, App no, 24833/94, Judgment of 18.2.1999; M.S.S. v. Belgium and Greece, App no, 30696/09, Judgment of 21.1.2011; Avotinš v. Latvia, App no, 17502/07, Judgment of 25.2.2014.

${ }_{54}$ Kadi, supra note 50 at par. 384.

${ }^{55}$ Ibid. at par. 368. 
the CJEU in Kadi has been associated with a dualist conception of the interplay between the international and the Union legal order" ${ }^{\prime 2}$. In this case, the said conception involved the EU and the UN (the Parties of which are all EU Member States). In the final part of the judgment, the Court provided that, in drawing up the necessary measures, "the Community is to take due account of the terms and objectives of the resolution concerned and of the relevant obligations under the Charter of the United Nations relating to such implementation" ${ }^{57}$. In this passage, the Court indirectly expressed the primacy of the UN's resolution over EU law. As an additional note, it is emphasized that, in general, the Court is not willing to accept the supremacy of legal norms of other international organizations to which its Member States are parties. This has been evidenced by various decisions delivered by the Court. ${ }^{58}$

The decision was implemented unilaterally by the CJEU on the European Union. Nevertheless, it is argued that it may be considered as an example that shows grounds for which international organizations may be recommended to accept standards emanating from obligations which are not legally binding on them. If Organization A implements measures imposed on its member state that is simultaneously a party to Organization B, it is endorsed that latter takes due account of the terms and objectives of the measures concerned. Based on the current findings of the research, this recommendation is explained by the will to harmonize international law standards.

It must be emphasized that the Court did not provide a definition of the 'due account' that would set out its minimum requirements. In the author's opinion, the concept may be understood as a variable on a two-point scale between the acceptance of the legal framework of the

${ }^{56}$ J. Kokott, C. Sobotta, The Kadi Case - Constitutional Core Values and International Law Finding the Balance?, "European Journal of International Law”, Issue 4, 2012, p. 1015-1024.

${ }^{57}$ Ibid., at par. 296. To this effect, see also: Art. 351 in fine TFEU.

${ }^{58}$ Cf. NV International Fruit Company and others v. Commission of the European Communities, Joined cases 41 to 44-70, Judgment of 13.5.1971, E.C.R. 1971; Portugal v. Council, Case C-149/96, Judgment of 3.12.1996, E.C.R. 1996; Leon van Parys v. Belgisch Interventie- en Restitutiebureau (BIRB), Case C-377/02, Judgment of 1.3.2005, E.C.R. 2005; FIAMM and Others v. Council and Commission, Joined Cases C-120/06 P and C-121/06 P, Judgment of 9.9.2008, E.C.R. 2008; Commission v. Rusal Armenal, Case C-21/14 P, Judgment of 16.7.2015, E.C.R. 2015. 
organization and the implementation of the law of that organization. This point of view is similar to the findings of N. Yang, who provided a comprehensive analysis of the judgment. She argued that on the one hand, the phrase may mean that "the EU should refrain from any action which could jeopardize the attainment of UN objectives" 59 . In this case, this would be no doubting the assessment made by the UN Sanctions Committee $^{60}$. On the other hand, she reckoned a more active possibility, i.e. attaching the same importance to the objective by the EU as by the UN. In casu, this objective was countering terrorism ${ }^{61}$. In relation to this, it is argued that the requirements to be implemented shall be assessed on a case-by-case basis. This assessment shall be conducted by the organization that aims to take due account of the measures and objectives pursued (referring to the mentioned examples - this would be Organization B).

\section{CONCLUSIONS}

Considering the abovementioned, new findings should be underlined. They are related to the implementation of measures imposed by Organization A on its member states that are simultaneously parties to Organization B. De lege, Organization B is not obliged to implement the discussed measures, because norms of international organizations have the same force in the international legal order (the exception to the rule is the law emanating from the United Nations, as follows from Art. 103 UN Charter ${ }^{62}$ ). Nevertheless, the norms of Organization A remain binding on its member states. Thus, the parties to Organization A may still be held liable for a violation (by act or failure to act) of the measures, even when

59 N. Yang, Constitutional dimensions of administrative cooperation: potentials for reorientation in Kadi II, [in:] M. Avbelj, F. Fontanelli, G. Martinico (eds.), Kadi on Trial: A Multifaceted Analysis of the Kadi Trial Abington: Routledge, 2014, p. 172-186.

60 Ibid.

61 Ibid.

${ }^{62}$ Art. 103 UN Charter: "In the event of a conflict between the obligations of the Members of the United Nations under the present Charter and their obligations under any other international agreement, their obligations under the present Charter shall prevail". 
acting in conformity with (or: on the basis of) the law of Organization B. There is a clear correlation between the functioning of international organizations which is linked by their mutual member states. For the sake of the need to preserve a harmonized international cooperation, organizations may take into consideration each other's interests. To refer to the provided example, it may happen that Organization B implements measures imposed by Organization A, thereby taking due account of the terms and objectives of the measures concerned.

Subject to this research, such a relationship has occurred between the EU (example Organization A) and NATO (Organization B). Owing to the fact that the majority of NATO States fall under the jurisdiction of the EU and that there are NATO headquarters in Europe, it was decided to implement the data protection policy, as regulated by the GDPR, at NATO level. In the author's opinion, thanks to this, the harmonious functioning of international legal order has been ensured. As already mentioned, one of the headquarters that decided on the implementation of (or: was inspired by) the GDPR is the Joint Force Command in Brunssum. The subsequent Chapter aims at providing an analysis concerning a divergent implementation of the Regulation. The hypothetical situation presents a problem and legal implications of taking no due account of the terms and objectives of the GDPR by JFCBS.

\section{Possible InCONSISTENCY BETWEEN NATO AND GDPR - A QUESTION ABOUT ACCOUNTABILITY}

\section{NO DUE ACCOUNT AND FURTHER RESPONSIBILITY- HYPOTHETICAL SITUATION}

In relation to the previous Chapter, it seems helpful to visualize the problem of the study by drawing a hypothetical situation. For the purpose of the research, it is assumed that NATO JFCBS, by means of the newly adopted Data Protection Directive, has developed a data protection policy that is inconsistent with the GDPR. This involves an imposition of a requirement on relevant national public authorities to provide the Command with sensitive personal data of the citizens of the 
Netherlands (receiving State ${ }^{63}$ ). The obligation is deprived of preventive measures in relation to this data, such as the possibility to process it only upon receiving the explicit consent from a data subject (see: Art. 9.2.a in conj. with Art. 9.1 GDPR). Since this is one of the most fundamental provisions and guarantees protection of personal data, such a norm may be considered as disobeying the due account requirement.

The purpose of this Chapter is to find the actor responsible for the abovementioned inconsistency. It is assumed that there are two possible options. On the one hand, the state responsibility (Netherlands) must be taken into consideration (IV.2.). It will be checked whether such liability could result from the activity of a national public authority, which eventually led to the breach of the relevant GDPR provisions. On the other hand, the responsibility of NATO as an international organization must also be examined (IV.3.). This will take into account whether the Organization may be held liable for enacting rules that are inconsistent with the GDPR based on the act (IV.3.A.) and imposing the obligation to act (IV.3.B.).

\section{State liability}

This part takes into consideration a hypothetical situation, in which a Dutch public authority is obliged to provide the Command with sensitive personal data of the citizens. Thus, the Section aims to find out whether the said activity may give rise to state liability. The study is based exclusively on EU law, for two reasons. Firstly, the Netherlands is a Member State of this Organization, and secondly, the violation of the GDPR (secondary EU law) is examined.

In Francovich, the Court listed the following grounds that give rise to state liability: 1) a breach of EU law that is 2) attributable to the Member State and 3) causes damage to an individual ${ }^{64}$. In casu, the establishment

${ }^{63}$ Art. 1.1.e. NATO SOFA defines the "receiving State" as "the Contracting Party in the territory of which the force or civilian component is located, whether it be stationed there or passing in transit".

${ }^{64}$ Andrea Francovich and Danila Bonifaci and others v. Italian Republic, Joined cases C-6/90 and C-9/90, Judgment of 19.11.1991, E.C.R. 1991. at par. 73. 
of the state liability was connected with the principle of loyalty enshrined in Art. 10 TFEU (ex Art. 5 EEC Treaty) ${ }^{65}$ and the obligation to preserve the new legal order introduced in Van Gend $\mathcal{E} \operatorname{Loos}^{66}$. However, it must be borne in mind that the case concerned the violation of a directive, whereas the instrument relevant for this research is a regulation. Do the Francovich criteria apply exclusively to directives, or does the validity of the decision extend to any source of EU law? The Court has not provided the answer to this question. A contrario, it is argued that the Francovich principle is universal and may also be applied to legislative acts different from directives. This is supported by the fact that, contrary to discussing the compensatory grounds for disobeying a directive ${ }^{67}$, the CJEU referred to EU law in general while establishing the principle of state liability. For that reason, it may be argued that Francovich criteria apply to situations like the one in question.

Having presented the foregoing, reference should be made to another judgment, which this time directly relates to the violation of a regulation. In Slaughtered Cows ${ }^{68}$, the Court ascertained that a Member State that does not give effect to a regulation has failed to fulfill the obligations imposed on that State by virtue of its adherence to the Treaty ${ }^{69}$. Such a violation does not give full effect to Community law and therefore is a violation of the abovementioned principle of loyalty ${ }^{70}$. Failure of a State to give effect to a regulation results in disrupting "the equilibrium between advantages and obligations flowing from its adherence to the Community" and creates discriminations at the expense of the nationals ${ }^{71}$. Furthermore, as held in $\mathrm{RuSSO}^{72}$, a Member State shall be liable for damages caused by an infringement of directly applicable Community law if that State would

${ }^{65}$ Ibid. at par. $35-36$.
${ }^{66}$ Ibid. at par. 31.
${ }^{67}$ Ibid. at par. $39-40$.
${ }^{68}$ Commission of the European Communities v. Italian Republic, Case C-39/72, Judgment of 7.2.1973, E.C.R. 1973.

${ }^{69}$ Ibid. at par. 25.

${ }^{70}$ Ibid.

${ }^{71}$ Ibid. at par. 24.

72 Carmine Antonio Russo v. Azienda di Stato per gli interventi sul mercato agricolo (AIMA), Case C-60/75, Judgment of 22.1.1976, E.C.R. 1976. 
be liable under a similar provision of national law ${ }^{73}$. At this point, it must be added that the notion of a 'state' encompasses "[a] body, whatever its legal form, which has been made responsible (...) for providing a public service under the control of the State and has for that purpose special powers beyond those which result from the normal rules applicable in relations between individuals"74. Therefore, a 'state' also comprises national public authorities if damage results from the exercise of their official functions.

For the sake of the foregoing, it is concluded that if a Dutch public authority provided JFCBS Command with sensitive personal data of the citizens, as required by the hypothetical provision of the JFCBS Data Protection Directive, this activity would lead to the liability of the Netherlands. The finding is based on the fact that the Francovich criteria would be met. Firstly, in the light of the GDPR, the sensitive data are not governed by the general principles for lawful processing; instead, the Regulation requires additional precautionary measures while processing this kind of personal information, one of them being the consent of a data subject ${ }^{75}$. Disrespecting this rule would be a clear violation of secondary EU law. Furthermore, the activity at stake would disturb the previously mentioned equilibrium between advantages and obligations emanating from EU law (Slaughtered Cows). Secondly, the breach would be attributable to the Netherlands, since it would be conducted by a public authority in the exercise of their official functions (Foster). Simultaneously, it would violate Sec. 22 of the Dutch Implementing Act of the GDPR ${ }^{76}$,

${ }^{73}$ Ibid., at par. 8-9. Cf. for interpretation J. E. Hanft, Francovich and Bonifaci v. Italy: EEC Member State Liability for Failure to Implement Community Directives, "Fordham International Law Journal", Issue 15, 1991, p. 1237-1274.

${ }^{74}$ Foster and Others v. British Gas, Case C-188/89, Judgment of 12.7.1990, E.C.R. 1990.

75 Cf. Art. 9 in fine GDPR.

76 Act of 16 May 2018 houdende regels ter uitvoering van Verordening (EU) 2016/679 van het Europees Parlement en de Raad van 27 april 2016 betreffende de bescherming van natuurlijke personen in verband met de verwerking van persoonsgegevens en betreffende het vrije verkeer van die gegevens en tot intrekking van Richtlijn 95/46/EG (algemene verordening gegevensbescherming) (laying down rules for implementing Regulation (EU) 2016/679 of the European Parliament and of the Council of 27 April 2016 on the protection of natural persons with regard to the processing of personal data and on the free movement of such data, and repealing Directive 95/46/EC (General Data Protection Regulation). 
thereby meeting the requirement expressed in Russo (infringement of a directly applicable law, see: Art 288 TFEU). In relation to this judgment, the Netherlands would be liable for damages caused by an infringement of directly applicable EU law. Thirdly, it would cause harm to individuals (violation of the right to privacy) and their rights guaranteed under the GDPR that are related to the processing of their personal data.

All things considered, it is clear that even though the public authority would abide by the obligations imposed by NATO, this would still amount to the violation of EU law. This is additionally strengthened by the fact that the obligation would emanate from an internal rather than legal instrument of the Command (JFCBS Directive). This finding is in conformity with the decision of the ECtHR (Bosphorus). Having in mind that this Court is an organ of the Council of Europe, one may argue that the examined activity could also be considered as a breach of the right to privacy enshrined in Art. 8 ECHR.

\section{RESPONSIBILITY OF INTERNATIONAL ORGANIZATION}

\section{A. RESPONSIBILITY ARISING FROM AN ACT}

The possibility of holding NATO (JFCBS) accountable for adopting norms inconsistent with the GDPR will be assessed on the basis of the Articles on the Responsibility of International Organizations of 2011 (ARIO). The ARIO were adopted by the International Law Commission ${ }^{77}$. Even though they are deprived of a legally binding force, they may be considered as an indicator of responsibility of international organizations, in that being a soft law. Art. 1.1 of the document provides for its ratione materiae. It states that the framework applies "to the international responsibility of an international organization for an internationally wrongful act". This Section examines whether the responsibility could arise from adopting measures by NATO that would be inconsistent with the GDPR. To this end, Art. 4 is analyzed along with other provisions, which are relevant to it.

77 'Resolution on the report of the Sixth Committee (A/66/473) Responsibility of international organizations' adopted by General Assembly (New York, 9 December 2011), A/RES/66/100. 
In the understanding of Art. 4, an 'internationally wrongful act' is conduct consisting of an action or omission that is attributable to that organization under international law and constitutes a breach of international law. With regards to the forgoing, in order to examine the probability of NATO's responsibility, an answer to the following questions is necessary: (i) Was there an action or omission?; (ii) If so, is it attributable to NATO?; (iii) Does it constitute a breach of international law?

(i) Was there an action or omission? The answer to the first question is affirmative, since the measures inconsistent with the GDPR would be adopted by NATO by means of the JFCBS Data Protection Directive.

(ii) Is the action attributable to NATO? Pursuant to Art. 2.a, the responsibility could arise from 1) an international organization, if 2) it has been established by a treaty, and 3) possesses its own international legal personality. The first two requirements giving rise to international responsibility would be met: NATO is an international organization established by the Washington Treaty (NAT). The problems may arise in relation to the last requirement, as the opinions concerning the legal personality of NATO diverge. One group of authors argues that NATO has legal personality ${ }^{78}$, which is "grounded in the international legal instruments agreed to by the states that create them and in the implied powers exercised and functions carried out by those organizations" 79 . In this sense, the Organization is claimed to be independent of its members ${ }^{80}$. The other group of authors claims that NATO has no legitimacy to act on its own ${ }^{81}$. This argument is supported by the fact that the Organization acts by consensus and therefore has no legal autonomy ${ }^{82}$. Nevertheless,

${ }^{78}$ H. G. Schermers, N. M. Blokker, International Institutional Law: Unity Within Diversity, Fifth Revised Edition, Leiden: Martinus Nijhoff Publishers, $5^{\text {th }}$ ed, 2011, p. 992.

79 J. E. Hickey Jr., The Source of International Legal Personality in the 21st Century, "Hofstra Law Faculty Scholarship", Issue 2, 1997, p. 1-18.

${ }^{80}$ M. Zwanenburg, Accountability under International Humanitarian Law for United Nations and North Atlantic Treaty Organization Peace Support Operations, Leiden: Martinus Nijhoff Publishers, 2005, p. 82.

${ }^{81} \mathrm{~J}$. d'Aspremont, Abuse of the Legal Personality of International Organizations and the Responsibility of Member States, "International Organizations Law Review", Issue 4, 2007, p. 91-119.

${ }^{82}$ Gazzini, supra note 36, p. 391-436. 
as emphasized by D. Nauta, international legal personality is presumed once an organization "performs acts that can only be explained on the basis of international legal personality, which - in the case of NATO must be presumed" ${ }^{\prime 3}$. Therefore, for the purpose of the analysis, the legal personality of NATO is accepted.

Additionally, in order to answer the question of whether NATO could be held responsible for adopting a/the data policy that is different from the GDPR, it is important to analyze Art. 10 and Art. 11 ARIO. The former provision states that a breach of an international obligation by an international organization occurs "when an act of that international organization is not in conformity with what is required of it by that obligation, regardless of the origin or character of the obligation concerned". Art. 11 adds that "[a]n act of an international organization does not constitute a breach of an international obligation unless the organization is bound by the obligation in question at the time the act occurs". Yet, it must be asked if there was a prior obligation for NATO to implement the GDPR. Based on the previous finding of the research - the answer to this question is negative. There is no legal obligation for NATO to implement the law of any other international organization. As presented in Chapter III, the lack of the obligation could nevertheless be mitigated by practical implications. The examples of cooperation between international organizations were presented by the reference to the jurisprudence of the ECtHR (Bosphorus) as well as of the CJEU (Kadi). The mentioned judgments presented the rationale behind the legal collaboration between different international organizations. Nevertheless, since they were imposed unilaterally by the Courts of the Council of Europe and the European Union, respectively, they are not legally binding on the states or entities which are not parties thereto (such as NATO). Taking everything into consideration, the answer to the second question is negative.

(iii) Does the action constitute a breach of international law? Since the premises of the responsibility of international organizations are cumulative and the previous requirement has not been met, the analysis could already be finished. Nevertheless, for the purpose of the research, it is

83 D. Nauta, The International Responsibility of NATO and its Personnel during Military Operations, Leiden: Martinus Nijhoff Publishers, 2017, p. 107. 
worth adding that the third condition giving rise to responsibility would not be met either. This follows from the fact that the GDPR amounts to a secondary source of EU law. Therefore, it does not give effect to international obligations; it only imposes the rules to be applied within the European Union. Taking the foregoing into consideration, it is concluded that JFCBS would not be held responsible for the adoption of norms inconsistent with the GDPR.

\section{B. RESPONSIBILITY ARISING FROM IMPOSING AN OBLIGATION TO ACT}

The part above analyzed whether NATO could be held accountable for imposing data protection norms that diverge from the GDPR. As demonstrated, such accountability would not arise, since NATO is not bound by the (secondary) legislation of the EU. Nevertheless, even though the GDPR norms do not extend to NATO, they remain binding on the Parties to the Organization that are simultaneously the Member States of the European Union. In the hypothetical case, NATO would impose an obligation on the Dutch authorities to conduct activities that would violate EU law, if those activities were to be performed by the Netherlands. This Section aims to examine whether NATO could be held responsible for the imposition of this obligation.

To this end, Art. 16 ARIO must be referred to. The provision states that an international organization which directs and controls a state in the commission of an internationally wrongful act by that state is internationally responsible for that act if the following requirements are met: (1) the organization does so with knowledge of the circumstances of the internationally wrongful act; and (2) the act would be internationally wrongful if committed by that organization. Based on the foregoing, in order to examine whether responsibility could arise, the following questions must be addressed: (i) Does NATO direct and control the Netherlands in the commission of an internationally wrongful act? (ii) Does NATO do it with knowledge of the circumstances of the internationally wrongful act? (iii) Would the act be internationally wrongful if committed by NATO?

(i) Does NATO direct and control the Netherlands in the commission of an internationally wrongful act? JFCBS would direct the public authorities of the Netherlands to provide it with sensitive data of the citizens. It is assumed 
that the Command would also control the authorities in the commission of this activity, as it would verify whether the relevant data has been delivered. As has been explained in the previous part (IV.2), the term 'national public authorities' falls within the definition of a 'state'. For that reason, the answer to the first part of the question would be affirmative. Nevertheless, as explained in the previous part, the action at stake would not constitute an 'internationally wrongful act', since the premises of Art. 4 would not be fulfilled. For that reason, the first requirement giving rise to responsibility is not met. The grounds giving rise to accountability as a result of directing and controlling a state to commit an internationally wrongful act are also cumulative. For that reason, it is not necessary to continue with an analysis of subsequent premises in order to conclude if such responsibility could arise. Nevertheless, for the sake of the further discussion and academic purposes, the remaining requirements will be addressed as well.

(ii) Does NATO do it with knowledge of the circumstances of the internationally wrongful act? The ARIO are silent when it comes to specifying what should be understood under the notion 'knowledge'. In the author's opinion, it should be established that the bona fide standard has been disregarded. To give an example, there should be a differentiation between a wrongful implementation caused e.g. by a mistake (like error of fact) and one resulting from the motivation to breach the rule emanating from the other organization. From among these two, the latter situation is more likely to be considered as 'knowledge' in the meaning of ARIO. Since NATO is not bound by EU law, it may be assumed that it would not impose the obligation on a Member State with knowledge that this would lead to the violation of law by that State.

(iii) Would the act be internationally wrongful if committed by NATO? As established in IV.3.A., the act would not be internationally wrongful if committed by NATO, since the premises of Art. 1.1 in conjunction with Art. 4 would not be met. There is no legal obligation for NATO either to implement the GDPR or to introduce measures consistently with this Regulation, which is why the answer to this question would be negative. In the light of the foregoing discussion, it is concluded that NATO would not be responsible for imposing the obligation to act. 


\section{CONCLUSIONS}

In relation to the findings, it may be argued that in situations such as the one which is the subject of this study, the problem should be analyzed beyond the standards of the ARIO, at least for two reasons. Firstly, the GDPR is a binding law for as many as 22 NATO States. Imposing rules that are inconsistent with the norms emanating therefrom would place these Member States in a difficult situation. In the example of the Netherlands: on the one hand, the State aims at abiding by the JFCBS Data Protection Directive. On the other, however, this would mean that the Netherlands would disregard the GDPR, which is legally binding within this State. The consequences thereof have been elaborated in IV.2. Secondly, in the current era of digitalization and technological development, privacy constitutes a very important and sensitive value. This value can be sufficiently preserved inter alia by data protection policies at national and international levels. The GDPR, along with other international conventions such as the European Convention of Human Rights (ECHR) or the International Covenant on Civil and Political Rights (ICCPR) may be considered as another means on the road to strengthen this protection.

For the sake of the foregoing, it may be said that NATO - as well as other entities, be they national or international - is advised to take due account of the terms and objectives of other data protection regulations. In such cases, the rules would not encompass exclusively the EU, but also other organizations such as the United Nations or the Council of Europe. This 'due account requirement', which was unilaterally imposed by the CJEU (Kadi) on the EU, is an example that explains why it is recommended to derive norms from documents which are not legally binding on a given entity. As presented in the previous Chapters, NATO is an international organization with a horizontal internal structure. For that reason, it is in its interests to see (i.e. to take due account of) what actions are undertaken by other organizations in given areas. This is even more understandable in the field of personal data protection, since the primary purpose of NATO is to regulate matters in the area of security and defence.

It must be emphasized that the aim of the discussion is not to present NATO/its Parties as being internationally accountable or as acting 
inconsistently with the legal norms of other organizations. The primary aim is to strengthen the effectiveness and reduce the fragmentation of international law. It is argued that if the 22 common Member States do not have to deal with the struggle concerning the application of incomprehensive legal norms imposed on them by different international organizations, they will be able to focus on the primary purposes of those Organizations. This may be ensured by a harmonious and consistent legal framework provided by the Organizations. In this regard, the GDPR could be an example that sets standards of the data protection policy. If these standards were reflected at NATO level, this would resemble the situation of the EU's acceptance of the NATO norms in the area of the CDSP. This, in turn, would be evidence of the enhanced legal cooperation between the Organizations.

\section{Final Conclusions and Recommendations}

The research provided an analysis of the relationship between two significant international organizations operating in Europe. Firstly, it demonstrated that the structure and internal functioning differ between them. The EU is characterized by a clear distinction between primary and secondary sources. Thanks to the developed internal dispute mechanism as well as the binding force of the CJEU's judgments, doctrines such as direct effect or supremacy over national law could be developed. This internal structure has ensured that many obligations have been met by the Member States. The legal construction of NATO is not similar. There is no division between primary and secondary legislation; there are only four multilateral documents that regulate the operation of NATO as an organization. Furthermore, there is no established judicial body and therefore no internal dispute mechanism. The lack of a crystal-clear legal system for NATO may be explained by the fact that the nature of the Organization is different as compared to the EU. The original goals vary between co-operation to maintain the necessary security and defence structure - autonomy which the states would probably not be eager to hand over to NATO and the assistance-like relations of the Member States in a more general scope of collaboration (EU). Nevertheless, despite the lack of a judicial structure stricto sensu, NATO has been a strong and 
prominent Organization for 70 years and the Founding Treaties thereof are of the same value as those of other international organizations.

It was found out that there are certain areas of cooperation between the Organizations of interest. According to the EU Treaty, the Union shall respect the obligations of the Member States who are parties to NATO in the field of the CDSP. It can be said that in this way the door towards their cooperation has been opened. The question raised in this research concerned an obligatory collaboration between these International Organizations, in the sense of setting up a requirement that one Organization implement the norms of the other. It was found that an international organization may not impose obligations on another. Thus, NATO is not bound by the EU measures and vice versa, unless otherwise agreed by these Organizations. Referring to the problem of the study, there is no legal obligation for NATO to implement the GDPR. Nonetheless, the Organization decided to consider the EU Regulation as a source of inspiration while working on its own data protection policy. As a result, there are many GDPR-like solutions in the relevant directives of the Supreme Headquarters Allied Powers Europe and the Joint Force Command in Brunssum.

The later part of the research studied the consequence of enacting the data protection rules by the JFCBS that would be inconsistent with the GDPR. This was based on a hypothetical situation. The imaginary circumstances concerned the obligation imposed on the Dutch public authorities to disclose sensitive personal data to the JFCBS without ensuring safety measures. The findings were established in relation to the state liability and the responsibility of international organizations. With regards to the former, the research was based on EU jurisprudence. It was demonstrated that the situation would make the Netherlands accountable, because the activity would constitute a violation of EU law. The breach would be attributable to the Netherlands, since it would be conducted by a public authority in the exercise of its official functions. Moreover, it would cause harm to an individual and his/ her rights related to the processing of their personal data.

In relation to NATO, the analysis was based on the Articles on Responsibility of International Organizations (ARIO). It consisted in checking the accountability on two different grounds. The first possibility included the enactment of an internationally wrongful act. It was 
concluded that the responsibility would not arise, since NATO has not been bound by the GDPR; moreover, the latter does not amount to international law, but rather secondary law of the EU. Therefore, there would be no breach of international law attributable to NATO. Secondly, the question was examined as to whether liability could arise from the directing of a state in the commission of an internationally wrongful act by an international organization. Nonetheless, the accountability would not take place either, as the similar requirements for internationally wrongful act attributable to NATO would not be established.

Although the EU and NATO have different policies (or regulations within the same policy) and there is no legal obligation to take into consideration each other's legal solutions, there is a strong need for collaboration between them. As established, this is explained by the necessity of harmonious international cooperation. This, in turn, is connected with the achievement of goals relevant for well-functioning within Europe, such as security and economic prosperity. As may follow from this paper, a very significant reason for cooperation proved to be the mutual Member States of these Organizations. The equal regulations between the Organizations would help in the more efficient achieving of their purposes, inasmuch as the Members would not have to seek solutions for the application of the conflicting norms. To come back to the research problem - even though NATO is not obliged to implement the GDPR, this Regulation is still binding on 22 of its Parties. Therefore, even though there is no legal obligation to implement or take into consideration the GDPR, it is advised "to take due account of the terms and objectives of the resolution concerned" for the purposes of practical and efficiency needs. Although the passage stems from the unilateral decision of the CJEU, and NATO was not included in the proceedings, the CJEU's decision may be considered as a universal guideline for third parties. In the author's view, the issue at stake amounts to a situation where due account of the terms and objectives of the GDPR should be taken. For that reason, it is also recommended to NATO headquarters other than JFCBS to implement, or at least be inspired by, the GDPR. Perhaps one day, along with clear collaboration in the area of the CDSP, the EU and NATO will share a common framework in the field of data protection policy? 